\title{
Do 'city shapers' really support urban consolidation? The case of Brisbane, Australia
}

\author{
Katrina Raynor (Corresponding Author) \\ Faculty of Architecture, Building and Planning, \\ The University of Melbourne, Victoria 3010, Australia \\ katrina.raynor@unimelb.edu.au
}

\section{Severine Mayere}

School of Civil Engineering and Built Environment, Queensland University of Technology, 2 George St, Brisbane 4001, Australia Severine.mayere@qut.edu.au

\section{Tony Matthews}

School of Environment, Griffith University, 170 Kessels Road, Brisbane 4122, Australia t.matthews@griffith.edu.au

\section{Full citation}

Raynor, K., Mayere, S. and Matthews, T. (2017) 'Do “City Shapers" really support urban consolidation? The case of Brisbane, Australia.' Urban Studies.

doi.org/10.1177/0042098016688420

\begin{abstract}
Cities all over the world have activated policy support for urban consolidation in recent decades. Rationales for urban consolidation focus on its perceived ability to achieve sustainability goals, including decreased automobile dependence, increased social cohesion and greater walkability. Despite this, there are few international examples of urban consolidation policy implementation that has achieved its stated aims. This paper explores the nature and character of perceptions of urban consolidation held by urban planners, developers, architects and local politicians. The perspectives held by these 'city shapers' are integral to urban consolidation debates and delivery, yet the nature and character of their specific views are underexplored in urban studies literature. This paper combines the theoretical lens of Social Representations Theory with the methodological approach of Qmethodology to understand the common sense understandings of urban consolidation held by city shapers in Brisbane, Australia. It identifies, synthesises and critically discusses the social representations employed by city shapers to understand, promote and communicate about urban consolidation. Findings indicate that urban consolidation debates and justifications diverge significantly from stated policy intentions and are based on differing views on 'good' urban form, the role of planning and community consultation and the value of higher density housing. We conclude that there is utility and value in identifying how urban consolidation strategies are influenced by the shared beliefs, myths and perceptions held by city shapers. Understanding these narratives and their influence is fundamental to understanding the power-laden manipulation of policy definitions and development outcomes.
\end{abstract}




\section{Introduction}

Cities all over the world have activated policy support for urban consolidation in recent decades (Newton and Glackin, 2014; Searle and Filion, 2011). While initially advocated as a way to mitigate inefficient and unnecessary expenditure on infrastructure at the city's edge, urban consolidation has increasingly been attributed with a wide range of alleged benefits (Dodson, 2010; Downs, 2005). It is now credited with the ability to achieve a number of sustainability goals, including decreased automobile dependence, decreased infrastructure provision costs, increased social cohesion and greater walkability (Grant, 2009; Newton and Glackin, 2014; Burchell et al., 2000). This focus on consolidation has been accompanied by a strong anti-suburban policy rhetoric reflected in Australia, North America and parts of Western Europe (Gleeson, 2008).

While there is a substantial body of literature devoted to testing the validity of sustainability claims (Mees, 2009; Williams, 2004), there is a dearth of research examining the perspectives of influential 'city shapers,' on urban consolidation. Little is empirically known at present about whether or not these actors support urban consolidation, why they embrace or reject it and whether they believe it positively or negatively impacts urban environments (Sivam et al., 2012). City shapers, defined in this paper as urban planners, developers, architects and local politicians, play a key role in the development, adoption and implementation of urban consolidation policies. This paper joins an existing debate within the Urban Studies Journal concerned with providing "a more systematic and sustained critical analysis to debates around the new imaginaries of new urbanism and smart growth [and a] ... direct engagement with the extant politics...found in these new urban imaginaries"(Gibbs et al., 2013: 2152).

This paper argues that density debates are often shaped by social and cultural perceptions and prejudices rather than purely technical analyses. Therefore, interrogating the perceptions of city shapers helps to highlight how various groups promote and comprehend various conceptualisations of urban consolidation to further their own interests. The paper begins with a review of literature concerned with Australian and international examples of urban consolidation, followed by a description and justification of Brisbane as a valid case study for identifying the constellation of attitudes associated with urban consolidation. It then provides a discussion of the relevance of Social Representations Theory for urban consolidation research. The next section outlines the process of Q-methodology and the application of this methodology in identifying areas of contention and clusters of stakeholders with similar social representations. The findings and discussion sections present the results of the analysis and 
discuss their implications for the delivery, negotiation and regulation of urban consolidation and higher density housing in Brisbane. The findings identify three key social representations prevalent in Brisbane based on differing views of the value of higher density housing, the role of planning in the development process, and opinions about what constitutes 'good' urban form. We conclude that city shaper social representations of urban consolidation often diverge from policy rhetoric and represent significant implications for the future of this urban form and the provision of higher density housing.

\section{Urban Consolidation: An international perspective}

The desire to manage growth and curtail urban sprawl is neither new nor endemic to Australia. Growth management strategies have formed a key aspect of planning policy in the UK, US, New Zealand, Australia and parts of Western Europe since World War II (Pollard, 2000). Differences in demographic and physical contexts have resulted in some variations in the aims and justifications of urban consolidation policies. In Europe, steadily declining urban populations have resulted in a compact city model focused on maintaining or increasing urban populations and making urban living popular again (Williams, 2004). In the UK, urban policy is more focused on providing high quality of life in city centres and developing infill sites (Williams, 2004). Compaction strategies in the US under the banner of 'smart growth' policies aim to achieve compact and contiguous development patterns, efficient delivery of public services and preservation of open space, agricultural land and environmentally sensitive areas (Burchell et al., 2000). Australian urban consolidation policy has employed a similar set of rationales to smart growth and focuses on managing rapid population growth and compromising higher density housing provision with a historical preference for suburban, detached housing (Newton and Glackin, 2014).

Despite international policy support for consolidation strategies, urban consolidation remains contentious and often inspires 'almost systemic' community opposition (Searle and Filion, 2011: 11). Similarly, scholars in Australia (Bunker, 2014), Canada (Grant, 2009) and the US (Downs, 2005) have noted a lack of implementation of consolidation and smart growth principles and the continuing development of conventional outer-city suburbs regardless of strong policy rhetoric supporting this urban form. A growing number of scholars have attributed this lack of successful implementation to the actions and attitudes of interest groups with little political will to promote sustainable urban consolidation outcomes (Rosol, 2013; Bunce, 2004). The limited research examining these questions has found that city shapers hold varying understandings of urban consolidation and often subvert policies to 
achieve their own interests (Jepson and Edwards, 2010; Grant, 2009).

These findings align with Australian research that highlights the ability of powerful interest groups such as industry lobbyists, planners and developers to shape housing debates, discourses and policy by communicating and promoting certain definitions of housing problems and solutions (Jacobs, 2015; Gurran and Ruming, 2015). Economic arguments about demand and supply and the detrimental impact of undue planning regulation and land restriction has come to constitute common-sense wisdom despite weak and contradictory evidence to support it (Gurran and Phibbs, 2013). Similarly, Gleeson (2014: 91) argues that consolidation continues to "reign in the court of planning" despite dubious evidence to support the planning policy. Several scholars (Rosol, 2013; Kern, 2007; Bunce, 2004) view consolidation processes as a function of capital accumulation rather than a sound planning consideration. In this context, greater focus on the motivations of the professionals involved in planning and delivering this policy is necessary.

\section{Brisbane as a case study for competing social representations of urban consolidation}

Brisbane is located in the South East Queensland (SEQ) region, one of the fastest growing regions in Australia (Steele and Dodson, 2014). The city provides a useful and relevant case study due to its historically dispersed urban form, increasing use of urban consolidation strategies, rapid increase in attached dwellings and its historical unfamiliarity with higher density housing (Buys and Miller, 2011). The South East Queensland Regional Plan 2009-2031 forecasts the need for 156,000 additional dwellings in Brisbane between 2006 and 2031, 88\% of which are purported to occur in areas targeted for consolidation (Queensland Department of Infrastructure and Planning, 2009). In this context of unprecedented change, Brisbane city shapers are required to navigate the political, social and environmental implications of a rapidly intensifying urban environment.

The Brisbane City Plan 2014 regulates local planning and seeks to advance state and regional planning policies (Brisbane City Council, 2014). The Plan includes zoning provisions that outline acceptable land uses in particular locations. Provisions concentrate growth in key nodes while retaining 'Suburban Living Areas' in which low density residential forms will remain the norm (Brisbane City Council, 2014). Both city-level and region-level plans advocate densification while allowing for the retention and 'protection' of large areas of low-density 'traditional' housing. This dichotomy sets the scene for many urban consolidation debates in Brisbane. 
The City Plan is formulated in accordance with the provisions set by the statutory South East Queensland Regional Plan 2009-2031, which guides growth and development in SEQ and outlines compact development as a key regional priority (Queensland Department of Infrastructure and Planning, 2009). The SEQ regional plan sets out an Urban Footprint, designed to contain urban expansion in the region. Planning in Brisbane and SEQ operates within a state-wide performance-based planning system designed to encourage flexibility and efficiency in the development process by assessing development proposals based on their merits and in keeping with community-based policy outcomes (Frew et al., 2016). While contentious, performance-based planning is predominantly advocated for its ability to reduce approval times, increase efficiencies, reduce negotiation and improve innovation in development proposals. Despite this, it is often criticised for not achieving the benefits it purports to deliver, for instance by lowering the standards of building regulation and by reinforcing the general climate and consequences of neo-liberal reform (Frew et al., 2016).

\section{A social constructionist approach to understanding perceptions of urban consolidation}

This paper employs Social Representations Theory (SRT) to capture and understand perceptions of urban consolidation. The theory, derived from social psychology, provides insight into the way taken-for-granted knowledge is shared between people in the same social milieu. The theory proposes that social representations (SRs) are mental constructs based on concrete images and abstract concepts that allow people to understand the world around them. They also allow people to communicate with others using shared structures of knowledge and symbols that influence how they discuss, conceptualise and react to a certain phenomenon (Wagner and Hayes, 2005). The theory is concerned with the ways in which people seek to understand, explain and articulate the complexity of stimuli and experiences in which they are immersed (Halfacree, 1993).

$\mathrm{SRT}$ is a novel addition to the repertoire of social constructionist theories often applied in urban and housing research. Social constructionist research, often undertaken using discourse analysis, has provided many valuable insights to urban scholarship based on the notion that what constitutes a social problem is malleable and is often the consequence of existing power hierarchies, vested interests, pressure group activity, media interest and institutional support (Jacobs et al., 2003). While this line of research has yielded a range of valuable insights into the framing of urban problems and solutions, it often uses 'sanitised' and edited public documents 
that reflect institutional narratives (Wolsink, 2004), but bear limited resemblance to underlying values, common-sense knowledge, beliefs and shared images that influence the construction of these narratives. In addition, the narrow focus on discourse analysis has deprived the field of the insights of other social constructionist contributions. SRT focuses on the psychological processes that must occur in order for individuals and social groups to make sense of the world (Halfacree, 1993). As Moscovici and Marková (1998) argue, people cannot construct socially without first having a shared representation.

Social Representations are structured mental content about socially relevant phenomena that function to make the unfamiliar more familiar and help to define what is 'visible' and must be responded to (Halfacree, 1993). They are not merely descriptive; they also function to tell people how things should be, and how individuals should behave in order to be consistent with general norms, values and social expectations (Radu and Redien-Collot, 2008). In this way, the SRs of urban consolidation revealed in this paper constitute the mental images and narratives applied by stakeholders when assessing and interacting with urban consolidation processes. They are used in the construction and interpretation of urban 'problems.' This is particularly pertinent as planners, developers, architects and local politicians play powerful roles as city shapers. Using SRT to elicit SRs held by these actors can be very useful in understanding the ways they feel and act in relation to urban consolidation and how they then shape the context of possible solutions and perceived problems.

\section{Identifying perceptions of urban consolidation using Q-methodology}

Social representations "form a structured, multi-dimensional portrayal of the subject area that is, a whole set of statements related to one another as a theory-like construct" (Wagner and Hayes, 2005: 120). Q-methodology offers a novel approach for identifying these theorylike constructs by explicitly asking participants to rank a large range of statements pertaining to a phenomenon to create a 'gestalt' conceptualisation of the topic. In light of this complexity, Q-methodology offers a way of revealing new patterns and connections in opinions that cannot be revealed by non-statistical techniques (Watts and Stenner, 2005).

The interaction of values and perspectives outlined by Q-methodology reveal what participants find most important, how they define and evaluate a large range of topics and how their opinions most differ from those held by others. Even a seemingly simple question about how various stakeholders interpret urban consolidation is a complex landscape of 
opinions, values, meanings and representations concerning the topic mediated by a range of cultural, contextual, political, socio-economic and physical factors (Duenckmann, 2010).

Q-methodology follows a five-step process, summarised in Figure 1. The current study proceeded in the following way; 1) Identification of an area of inquiry and population; 2) Collection of representative statements, based on newspaper articles and interviews undertaken with a range of Brisbane city shapers (see Table 1 for a full list of statements); 3) Q-sort interviews with 23 influential city shapers who were asked to sort the 50 statements from most agree to least agree while explaining their decisions; 4) An inverted factor analysis of the statements to identify 'factors', made up of participants who sorted their statements in a similar way and 5) Interpretation of the quantitative results supplemented by analysis of the interview transcripts.

\section{INSERT FIGURE 1 HERE}

\section{Findings: Key social representations of Brisbane's city shapers}

The statistical analysis of the 23 Q-sorts identified 3 key clusters of Brisbane city shapers who sorted their statements in similar patterns, thus revealing shared SRs (See Table 1). These SRs define the political, social, environmental, economic and ethical statements that make up a holistic view of this planning strategy and provide a lens for understanding how urban consolidation is defined, evaluated, communicated and shared by Brisbane city shapers.

In keeping with the theoretical basis of SRT, Q-methodology is concerned with the collective images that mirror the values and preferences of certain social groups rather than the individual attributes of test persons (Duenckmann, 2010). Despite this, there was a substantial, though not unanimous, clustering of respondents based on their area of professional endeavour. Factor One largely contains developers involved in the production of large-scale greenfield developments, whereas Factor Two contains developers and planners with interests in the development of a variety of housing styles and Factor Three features a higher proportion of government planners and developers involved in high density housing. This suggests that the mental constructs articulated by respondents largely correlates with their professional position. Each of these factors is analysed below. 


\section{INSERT TABLE 1 HERE}

Factor One: 'The 'Australian Dream'

Factor One consists of one private sector planner and two developers, one involved in a variety of development forms and one involved purely in the production of large-scale greenfield developments. Significantly, while this factor represented the constellation of opinions, values and ideas revealed by the Q-sorts of these 3 participants, it was diametrically opposed to the Q-sort of a local politician. This phenomenon, referred to as a bipolar factor (Watts and Stenner, 2005), has precedence in Q-methodology and is indicative of the levels of conflict recounted in interviews with city shapers. The description of this factor will proceed with a discussion of the viewpoints of the planner and developers but acknowledges that the local councillor upholds a diametrically opposed SR.

This factor is characterised by three representative elements: 1) support for greenfield development and limited planning regulations; 2) negative views on apartment living and; 3) a deep cynicism towards community consultation processes. This SR includes an image of planners as ignorant or powerless and views planners and developers as opponents. This contradicts much research that identifies an increasingly an pro-growth planning agenda in Australia (Ruming and Gurran, 2014) market-oriented roles for planners (Steele, 2009).

Reflecting much of the industry rhetoric identified by Gurran and Ruming (2015), the SR upheld by this factor contains narratives about housing affordability, land constraints and unmet housing demand. Participants refute the notion that development on the city outskirts should be curtailed to protect natural habitat and farming land, calling on the right to familyappropriate housing and economic efficiency arguments to support this position. This SR perceives the Urban Footprint, established in the SEQ Regional Plan 2009-2031, as an artificial barrier to the growth and development of the area. There is also a strong belief that greenfield development can be environmentally sustainable and that higher density housing does not result in a lower carbon footprint.

This factor also features a 'traditional' view of homeownership and housing, as proponents emphasise the tendency of families with children to gravitate to detached housing. The imagery associated with the 'Australian Dream' of a detached house on a quarter acre block is prevalent in this factor. Home-ownership is represented as an important financial and 
emotional decision and detached homes are seen as optimal housing choices. Respondents suggested apartments are only appropriate for investors and young childless households and that those choosing to buy apartments are often irresponsible or uninformed. Respondents from this factor often referenced high levels of investment from Chinese buyers, suggesting these investors purchased apartments as a tax offset with no intention of ever renting them to tenants.

Finally, the factor reflects frustration towards the implementation of neighbourhood plans and views consultation processes as a self-interested game. Respondents disparage community consultation processes and neighbourhood planning for restraining development. Factor respondents also view planning decisions as highly political and dependent on election cycles, recounting stories of local politicians pushing an insincere anti-development agenda as part of their election platform.

Factor Two: Neo-liberal business-as-usual

Factor Two consists of three private-sector planners, two architects, three developers and a government planner. Most respondents in this factor are engaged in delivering both high and low-density housing developments. The factor represents: 1) strong support for all forms of housing development; 2 ) a belief that current community consultation processes and planning processes are satisfactory and; 3) support for growth and market-lead development processes. This factor utilises a neo-liberal discourse, advocating greater flexibility in neighbourhood plans to allow developers to create economically viable projects. Growth in medium density housing is considered a function of market demand and apartments are praised for their convenience in terms of access to employment. The factor supports infill development, invoking the economic concept of supply and demand to suggest that more infill housing will increase housing affordability in Brisbane.

The SR upheld by this factor contains a highly positive conceptualisation of community engagement processes characterised by efficiency and equity, consistency and sincerity. Respondents refute the idea that residents are having higher densities forced upon them without consultation and believe that that neighbourhood plans are being appropriately enforced. Factor respondents believe that consolidated development in Brisbane occurs through regulated planning channels rather than through ad-hoc opportunism. Members of this cluster tend to believe that community opposition reflects an ignorance of planning 
legislation, with community members confusing acceptable outcomes with prescribed outcomes within a performance-based planning context. Significantly, many respondents stated their belief that community groups have too much power in shaping development decisions in Brisbane and that neighbourhood planning should be more 'visionary' to avoid conflict with communities in the future. Respondents referenced the needs of the wider community, the capacity of community groups to increase housing costs by increasing developer costs and the 'greater good' to justify this position. This novel insight into the ways planners evaluate and perceive community consultation is rarely reflected in scholarship.

This SR is also strongly supportive of growth, suggesting SEQ is not overcrowded. Like Factor One, it refutes the notion that expansion at the city edges is unnecessary and detrimental to the environment and existing farming land arguing that greenfield housing is essentially to meeting demand for housing in SEQ. Respondents believe much-needed housing supply is constrained by excessive regulation and community opposition. This factor reflects a SR with positive perceptions of the development industry, refuting notions of 'greedy' or 'narrowminded' developers.

\section{Factor Three: Apartment Advocates}

Factor Three consists of three private sector planners, three government planners, two developers engaged in the development of high density housing and one local politician from a rapidly growing council ward. This factor strongly represents: 1) apartments as a legitimate housing form; 2) urban consolidation as a beneficial planning policy, despite its potential shortfalls and; 3 ) the key role of market-driven development. Respondents believe that significant cultural change is taking place in terms of attitudes towards apartment living. They believe that apartments can appeal to a broad segment of the population. This stands in contrast to the negative perceptions expressed in the other factors. Significantly, these respondents strongly believe that people only desire large backyards because it is the norm they grew up with, and that this norm is changing. However, their SR of diversity in terms of apartment living rarely extends to children. Despite increasing policy rhetoric supporting housing diversity and child-friendly cities, this rarely enters the SR of higher density housing upheld by Factor Three.

This factor reflects much of the arguments used in planning documents to justify consolidation policies in Australia. Respondents support higher density for its ability to increase public 
transport usage and decrease carbon footprints, echoing the SEQ Regional Plan's assertion that "transport plays a fundamental role in SEQ's sustainability and is best supported in a compact urban form" (Queensland Department of Infrastructure and Planning, 2009: 90). Factor Three believe a large proportion of housing demand can be met through infill development and that urban sprawl is detrimental and should be constrained whenever possible. Despite this, the factor also acknowledges the potential of urban consolidation processes to push lower-income households to the outskirts of the city. Many respondents view this as an inevitable outcome of demand and market forces. Respondents deny that additional infill housing will increase housing affordability in Brisbane, noting the ability for developers to charge more for inner-city sites and the propensity for developers to build lower-density infill targeted at the upper end of the market rather than higher density lower cost housing. They also strongly believe that sense of community is lower in higher density housing.

Like Factor One and Two, Factor Three supports greater flexibility for developers and acknowledges the role of market-demand in driving development of medium density housing provision. This belief is moderated by a more constrained view on growth as this factor is the least likely to believe that development opportunities are constrained in SEQ and that developers are struggling to deliver housing in an overly-regulated system. Factor Three does not perceive of a great antagonism between planners and developers in the development process. In this way, they contradict the SR of Factor One and challenge the deregulation and land release rhetoric highlighted by Gurran and Ruming (2015). This factor places a higher value on community engagement than the other two factors, noting the need for community members to balance developers' proposals and suggesting that local communities have an important role to play in shaping how their neighbourhood will develop.

\section{Discussion}

Applying the theoretical framework of SRT and Q-methodology allows for common-sense understandings of urban consolidation to be discerned. Findings reflect previously-noted discourses of anti-regulation, the primacy of homeownership, community engagement, innercity consumption landscapes and anti-urban sprawl agendas. Factors ostensibly reflected 'status quo' positions based on professional affiliations. However, the novel approach applied in this paper allows for a nuanced investigation of the ways these hegemonic discourses are justified, refuted, challenged and expanded by specific stakeholders. By drawing upon SRT, 
greater insight is given to the underlying narratives, images, tropes, values and ideas used by stakeholders to interpret existing planning policy and development outcomes. The following discussion provides insight into the key themes that shape urban consolidation debate in Brisbane and the narratives, causal explanations and values employed by participants to support their positions. The key themes to emerge from the Q-sort analysis and interviews were: 1) perceptions of 'good' urban form; 2) views on the legitimacy of planning and consultation processes, and the flexibility and restrictions of planning regulation and; 3 ) perceptions about the suitability of apartments as a legitimate housing option.

\section{'Good' Urban Form}

The question of what constitutes a 'good' urban form is a fraught topic that has inspired much academic debate (Burton, 2000; Camagni et al., 2002; Talen and Ellis, 2002) and is contested in practice and in the understandings of the general populace (Jepson and Edwards, 2010). This Q-study reveals widely divergent taken for granted assumptions about 'good' urban form with significant implications for the way development and planning occurs in Australia and internationally. Factor Two and Three agreed that increasing density improves public transport outcomes and reduces carbon footprints. In keeping with much literature that has noted the increasing emphasis on densification in planning policy (Gleeson, 2014), a respondent referred to this notion as 'Planning 101' (Private Planner 4). Despite this, the belief that density alone can substantially improve public transport outcomes is roundly critiqued in planning scholarship. Mees (2010: xi) argued that the miss-guided idea that compact cities "can provide a substitute for getting policies and planning right... has been wide-spread across the 'Anglosphere' for at least two decades," and has resulted in a disproportionate focus on density at the expense of other potential sustainability measures.

The Q-sort interviews reflected a false dichotomy between urban sprawl and urban consolidation and an overly deterministic perspective on the role of density in impacting sustainability outcomes. While there is substantial opportunity for higher densities to deliver better urban forms, condensing the debate from a 'densification is good and suburban expansion is bad' dichotomy is a simplification that serves to 'greenwash' inner city development (Kern, 2007). This is reflected in an interview with a government planner who expressed support for higher density housing and noted the carbon intensity of providing infrastructure for greenfield development;

"In the short term the amount of carbon invested in a high rise building is a lot more than invested in a project home at the fringe. I think it is the nature of the materials... 
And I have seen a lot of studies that suggest that that in itself means that these are more carbon intensive than a project home. But it doesn't ever take account the fact that if you build a new development in South Brisbane you are not extending one square $\mathrm{cm}$ of road or pavement to service that area while that house out there has required a massive amount of infrastructure to open it up." - Government Planner 5

While this quote reflects a nuanced understanding of life-cycle sustainability outcomes, it naturalises the carbon-intensive nature of high rise developments. Similarly, an interview with a councillor reflects a simplified SR of the benefits of urban consolidation.

"We are out of greenfield sites in Brisbane so we have to go up and I am a true believer that up rather than out is better for our environment and biodiversity." - Councillor 2 The term 'going up rather than out' is a common motif when discussing urban consolidation and serves to simplify sustainability outcomes to purely a function of density and built form.

The research also reveals that many of the sustainability rationales used to support urban consolidation are substantially refuted, silenced or qualified by city shapers in Brisbane. Factor One staunchly refuted the notion that urban consolidation is better for the environment suggesting that "we keep being fed this nonsense from public transport agencies and governments of various persuasions that we can't have good public transport because we aren't all living in apartments above railway stations" (Developer $\mathrm{x}$ ). The reference to "being fed nonsense' alludes to the political nature of 'the truth' in sustainability debates. As Gunder (2006) argues, sustainability is a highly malleable term that can be used by different stakeholders to support their claim.

Proponents of greenfield development in Factor One focused on consumer choice, highest and best use and housing affordability justifications to support suburban expansion, arguing that "families still deserve, and have the right in Australia, while we have 24 million people rather than 50 million people, to be able to have a house with a backyard" (Developer $\mathrm{x}$ ). Even those who supported the urban footprint in principle acknowledged the prevalence of detached housing preferences and their effect on housing provision and urban expansion. As a government planner noted:

"It doesn't matter if you build a whole city, people actually have to want to live in it. So what people want requires us to go out into the suburbs and we are now having this problem where we have a growth projection where we won't have enough land to fit 
all these people to 2041. We are going to have to allocate more land and that is going to take farming land. But how do you control population?" - Government Planner 2

This quote is indicative of the growing gap between urban development discourses and the urban development reality observed by Filion (2010) and planner's love/hate relationship with the suburbs noted by Grant (2009) in North America. While respondents acknowledged the environmental and social challenges associated with continued outward expansion there was a commonly-cited belief that such growth was inevitable and expansions to the Urban Footprint will continue to occur. It is indicative of a gap between policy rhetoric and city shaper perceptions identified throughout the Q-sort interviews.

\section{Consultation and regulation}

The Q-study revealed several theoretical and practical insights pertaining to urban consolidation. Significantly, it reflects previous observations about the increasingly neoliberal role and perspective planners, highlights the challenges inherent in performance-based planning and draws attention to debates about the impact of the Urban Footprint and land constraints. The Q-study revealed unanimous agreement with the notion that "Developers need the flexibility to develop something economically feasible even if it doesn't completely conform with the plan" (Q-statement 19). Government and private planners alike commented on their role in facilitating development and managing the need for growth with community expectations with one planner explaining;

"[Antagonism between planners and developers] was the model when I started 30 years ago. Performance based planning has changed that but there has been an attitude shift here [in local government]. It is about facilitating and getting good outcomes." - Government Planner 1

This is in keeping with the move away from planning as a mechanism to correct and avoid market failure and toward a focus on de-regulation, privatisation, outsourcing and entrepreneurialism in planning (Hamnett, 2000; Steele, 2009).

However, the primacy of development perspectives did not go unchallenged in the Q-study. Planners, developers, architects and councillors commented on the challenges inherent in performance-based planning. An architect referred to the belief that neighbourhood plans aren't correctly enforced as "essentially an ignorance of state planning legislation and 
performance-based planning opportunities." In contrast, a government planner referred to the challenges and inconsistencies inherent in current planning processes, stating;

"We go out and make a promise to the community that we are going to do a plan with them and look at their wants needs and desires for the area. Then we do something like approve a building that is twice as high as the acceptable outcome. And those aren't views and results which are actually driven by the planning system. At the present time there is an ambit claim [process] so developers know they can make a claim and sometimes they'll go 'oh wow, we got that.'"' - Government Planner 1

These findings suggest there is room to improve the application of performance-based planning and the process of ambit claims. In Melbourne, the capacity for ambit claims has been attributed with encouraging land speculation, perverse development outcomes and increased building heights (Woodcock et al., 2011). This study suggests a similar process is occurring in Brisbane and city shapers are aware of its impacts.

City shapers are also aware of the impact of lobby groups and their advocacy for land release and expansion of the Urban Footprint. Gurran and Ruming (2015) have noted the prevalence of anti-regulation discourses and a focus on the role of land constraints as a factor in increasing house prices. This rhetoric is reflected in the SR applied by all respondents in Factor One who commented on the detrimental impacts of land supply constraint, overly restrictive planning regulation and the impact of NIMBYism (Not In My Back Yard) on housing supply and prices.

However, this Q-study suggests this rhetoric is challenged by planners. When presented with the statement "There are very severe constraints on the amount of land available for greenfield development and that's what makes housing unaffordable" (Q-Statement 40), one planner commented;

"Was someone from the UDIA behind that? They have got members who are greenfield developers and that is where they make their big bucks. Is that the right way to do things? They will tell you it is. Of course they will." - Private Planner 6

Similarly, multiple respondents referred to land-banking activities as an alternative explanation for housing supply constraints. These perspectives are pertinent as research from Australia (Gurran and Phibbs, 2013), New Zealand (Murphy, 2014) and the UK (Adams, 2011) have 
noted an on-going emphasis on planning deregulation and land release as a response to increasingly unaffordable housing despite dubious evidence of its efficacy. In line with these studies, this paper further emphasizes the political and power-laden construction of housing problems and solutions, identifying the conscious creation of SRs concerned with land supply and planning regulation.

\section{Higher density housing}

The SRs surrounding higher density housing in Brisbane reveal concerning trends for the future of this housing and urban form. Despite Factor Two and Three broadly supporting this housing type, most respondents maintained a belief that higher density housing was inappropriate for families with children. Respondents suggested that it is harder to raise children in higher density and that Gen $\mathrm{Y}$ is likely to move to the suburbs once they have children. This SR, coupled with the concentration of one and two bedroom apartments in the inner city has the potential to encourage social segregation in consolidating cities. Randolph (2006) predicted this challenge, arguing that apartment delivery is likely to cause segregation based on lifestyle and age as young professional couples and empty-nesters dominate renewed centres and families with children are consigned to the suburbs. The Q-study suggests that there is a pervasive SR amongst many city shapers that families with children simply do not live in high density environments. As one developer noted;

"The demographic around here is the 25 to 35 year olds who are not really interested in owning a home and want to spend their money going out and doing other things. That changes when you introduce kids" - Developer 6

Attracting and retaining (childless) consumer citizens to the inner city articulates neatly with a neoliberal agenda of urban growth, competition, and commodification (Kern, 2007). This presents challenges as a child-free discourse can serve to legitimise a lack of familyappropriate amenities in inner-city areas and can further entrench social segregation based on lifestyle and age (Fincher 2004).

Urban consolidation can also result in segregation based on socio-economic status. The current Q-study revealed an almost unanimous view that higher density housing is rarely affordable and that displacement of lower income households is inevitable. According to government planners this outcome "is just how it is" (Government Planner x). Similarly, commenting on affordable housing in the inner city, one developer naturalised the spatial segregation of different households and income groups, saying; 
"I think we have affordable housing in the city. I think that comes down to you can buy a $\$ 300,000$ apartment in the inner north but it is going to be a one bedroom apartment versus if you go and live $20 \mathrm{~km}$ out then you are going to get a 3 bedroom house. So I think if you are poorer you can't complain that you aren't living close to the city. You can afford a place, it is just a different product." - Developer 7

Far from reflecting the needs of a wide range of occupants, the Q-sort interviews revealed that the delivery of higher density housing is predominantly a function of investor demand and access to finance. Discourses were linked to market driven trends of foreign investments. One respondent, commenting candidly on the construction of apartments, noted the impact of the investor-focus on apartment design, saying:

"Investors will spend \$350k or \$400k so we designed to meet that budget. There was not a consideration of who would actually live in there - they were just like 'let's cut all this shit out to make the budget' because 90+\% were going to investors." - Developer 2

This trend towards investor-focused development presents considerable challenges for the longevity of high density housing. In the UK (Lambert and Boddy 2010) and Melbourne (Birrell and Healy, 2013), the influx of investor capital into inner-city areas has been attributed with increasing the risk of price fluctuations, high levels of vacant properties and the development of small apartments with little long-term appeal to occupants. This trend is reflected in Q-sort interviews in Brisbane as respondents reported a belief that 'excessive' apartment development in Brisbane is resulting in oversupply, under-occupancy and an impending market correction. These trends were seen to be creating potential problems including overseas buyers not paying body corporate fees and renters not caring about building upkeep, thus creating challenges for on-going upkeep of these buildings. This paper's findings paint a specific view of apartments - either as luxury items developed in response to the cosmopolitan tastes of an elite, childless sub-class of the population or as a fraught investment product with a limited shelf-life. Neither SR bodes well for the creation of sustainable, sociallyintegrated communities of higher density housing.

\section{Conclusion}

Urban consolidation is a common but controversial planning and housing strategy that is characterized by multiple levels of complexity. Its acceptability has been challenged, especially 
from a community perspective. However, there is substantially less evidence of how this strategy is perceived, understood and acted upon by the built environment professionals who are central to shaping and implementing cities and urban development strategies. This knowledge gap was addressed by this paper through its analysis of how 'city shapers' perceive and socially represent urban consolidation in Brisbane. The study joins an established research stream that examines the sociological dimensions of density (Batten, 1999; Fincher, 2007) and considers the political and value-laden nature of urban consolidation (Gibbs et al., 2013). Using the highly relevant case of Brisbane, Australia, the study applied an inductive approach to theory-building to identify areas of the urban consolidation debate that were previously under-explored.

The use of Social Representations Theory and Q-Methodology in this paper revealed new patterns and connections in opinions expressed by a targeted group of city shapers. Key perspectives held by city shapers centered around three themes: 1) attitudes towards 'good' urban form; 2) views on planning regulation and the legitimacy of the development and consultation process and; 3 ) housing choice and apartment living. The first theme identified a false dichotomy between sustainable urban consolidation and unsustainable urban sprawl and revealed that much policy rhetoric surrounding urban consolidation is challenged or ignored by city shapers. The second theme revealed significant divergences in perceptions of the quality of community consultation and neighbourhood planning in Queensland. The Q-study revealed nuanced evaluations of the role of community consultation, planners and developers within a neo-liberal context that would benefit from future research. The third theme positioned higher density housing as a luxury housing choice for childless households or an investor product with limited longevity. These beliefs shape the context in which urban consolidation is delivered and planned in Brisbane and represent a novel insight into the ways in which policy discourses and socially-shared representations differ. Further research comparing different cities could provide greater insight into the impact SRs have on urban outcomes.

Planning policies in many cities support urban consolidation and uphold the ability of higher density housing to adequately meet the needs of wide demographic. This narrative was not always reflected in findings from Brisbane. Overall, our research indicates that urban consolidation debates are rarely settled. We found them to be multi-faceted, complex and based on conflicting perspectives. These perspectives are powerful influencing mechanisms mediating the urban form of cites. We conclude that there is utility and value in identifying 
how planning strategies and urban developments are influenced by the shared beliefs, myths and perceptions held by city shapers. Understanding these narratives and their influence on city shapers is fundamental to more fully understanding the context of urban consolidation implementation in any city.

\section{References}

Adams D. (2011) The 'Wicked Problem' of Planning for Housing Development. Housing Studies 26: 951960.

Batten DC. (1999) The Mismatch Argument: The Construction of a Housing Orthodoxy in Australia. Urban Studies 36: 137-151.

Birrell B and Healy E. (2013) Melbourne's High rise Apartment Boom In: Research CfPaU (ed). Melbourne: Monash University.

Brisbane City Council. (2014) Brisbane City Plan 2014.

Bunce S. (2004) The emergence of 'smart growth' intensification in Toronto: environment and economy in the new official plan. Local Environment 9: 177-191.

Bunker R. (2014) How Is the Compact City Faring in Australia? Planning Practice \& Research 29: 449-460.

Burchell RW, Listokin D and Galley CC. (2000) Smart growth: More than a ghost of urban policy past, less than a bold new horizon. Housing Policy Debate 11: 821-879.

Burton E. (2000) The compact city: Just or just compact? A preliminary analysis. Urban Studies 37: 19692006.

Buys L and Miller E. (2011) Conceptualising convenience: Transportation practices and perceptions of inner-urban high density residents in Brisbane, Australia. Transport Policy 18: 289-297.

Camagni R, Gibelli MC and Rigamonti P. (2002) Urban mobility and urban form: the social and environmental costs of different patterns of urban expansion. Ecological Economics 40: 199216.

Dodson J. (2010) In the Wrong Place at the Wrong Time? Assessing some Planning, Transport and Housing Market Limits to Urban Consolidation Policies. Urban Policy and Research 28: 487-504.

Downs A. (2005) Smart growth: why we discuss it more than we do it. Journal of the American Planning Association 71: 367-378.

Duenckmann F. (2010) The village in the mind: applying Q-methodology to re-constructing constructions of rurality. Journal of Rural Studies 26: 284-295.

Filion P. (2010) Reorienting Urban Development? Structural Obstruction to New Urban Forms. International Journal of Urban \& Regional Research 34: 1-19.

Fincher R. (2007) Is high-rise housing innovative? Developers' contradictory narratives of high-rise housing in Melbourne. Urban Studies 44: 631-649.

Frew T, Baker D and Donehue P. (2016) Performance based planning in Queensland: A case of unintended plan-making outcomes. Land Use Policy 50: 239-251.

Gibbs D, Krueger R and MacLeod G. (2013) Grappling with Smart City Politics in an Era of Market Triumphalism. Urban Studies.

Gleeson B. (2008) Waking from the dream: towards urban resilience in the face of sudden threat. Urban Studies 45: 2653-2668.

Gleeson B. (2014) The urban condition: Routledge.

Grant JL. (2009) Theory and practice in planning the suburbs: Challenges to implementing new urbanism, smart growth, and sustainability principles 1. Planning Theory \& Practice 10: 11-33.

Gunder M. (2006) Sustainability: Planning's Saving Grace or Road to Perdition? Journal of Planning Education and Research 26: 208-221.

Gurran N and Phibbs P. (2013) Housing supply and urban planning reform: the recent Australian experience, 2003-2012. International Journal of Housing Policy 13: 381-407.

Gurran N and Ruming K. (2015) Less planning, more development? Housing and urban reform discourses in Australia. Journal of Economic Policy Reform: 1-19.

Halfacree KH. (1993) Locality and social representation: Space, discourse and alternative definitions of the rural. Journal of Rural Studies 9: 23-37.

Hamnett S. (2000) The late 1990s: competitive versus sustainable cities. In: Hamnett S and Freestone R (eds) Australian Metropolis: A Planning History. London: Mansell. 
Jacobs K. (2015) The 'Politics' of Australian Housing: The Role of Lobbyists and Their Influence in Shaping Policy. Housing Studies 30: 694-710.

Jacobs K, Kemeny JIM and Manzi T. (2003) Power, Discursive Space and Institutional Practices in the Construction of Housing Problems. Housing Studies 18: 429-446.

Jepson EJ and Edwards MM. (2010) How Possible is Sustainable Urban Development? An Analysis of Planners' Perceptions about New Urbanism, Smart Growth and the Ecological City. Planning Practice \& Research 25: 417-437.

Kern L. (2007) Reshaping the Boundaries of Public and Private Life: Gender, Condominium Development, and the Neoliberalization of Urban Living. Urban Geography 28: 657-681.

Mees P. (2009) How Dense Are We? Another Look at Urban Density and Transport Patterns in Australia, Canada and the USA. Road \& Transport Research: A Journal of Australian and New Zealand Research and Practice 18: 58-67.

Mees P. (2010) Transport for suburbia: beyond the automobile age: Earthscan.

Moscovici S and Marková I. (1998) Presenting Social Representations: A Conversation. Culture \& Psychology 4: 371-410.

Murphy L. (2014) 'Houston, we've got a problem': The Political Construction of a Housing Affordability Metric in New Zealand. Housing Studies 29: 893-909.

Newton P and Glackin S. (2014) Understanding Infill: Towards New Policy and Practice for Urban Regeneration in the Established Suburbs of Australia's Cities. Urban Policy and Research: 1-23.

Pollard OA. (2000) Smart growth: the promise, politics, and potential pitfalls of emerging growth management strategies. Va. Envtl. LJ 19: 247.

Queensland Department of Infrastructure and Planning. (2009) South East Queensland Regional Plan 2009-31. In: Planning QDola (ed). Brisbane: Southern Region Division.

Radu M and Redien-Collot R. (2008) The Social Representation of Entrepreneurs in the French Press: Desirable and Feasible Models? International Small Business Journal 26: 259-298.

Randolph B. (2006) Delivering the compact city in Australia: current trends and future implications. Urban Policy and Research 24: 473-490.

Rosol M. (2013) Vancouver's “EcoDensity" Planning Initiative: A Struggle over Hegemony? Urban Studies 50: 2238-2255.

Ruming K and Gurran N. (2014) Australian planning system reform. Australian Planner 51: 102-107.

Searle G and Filion P. (2011) Planning Context and Urban Intensification Outcomes: Sydney versus Toronto. Urban Studies 48: 1419-1438.

Sivam A, Karuppannan S and Davis M. (2012) Stakeholders' perception of residential density: a case study of Adelaide, Australia. Journal of Housing and the Built Environment 27: 473-494.

Steele W. (2009) Australian urban planners: hybrid roles and professional dilemmas? Urban Policy and Research 27: 189-203.

Steele W and Dodson J. (2014) Made in Queensland: planning reform and rhetoric. Australian Planner 51: 141-150.

Talen E and Ellis C. (2002) Beyond Relativism: Reclaiming the Search for Good City Form. Journal of Planning Education and Research 22: 36-49.

Wagner W and Hayes N. (2005) Everyday Discourse and Common Sense: the theory of social representations, New York: Palgrave Macmillan.

Watts S and Stenner P. (2005) Doing Q methodology: theory, method and interpretation. Qualitative Research in Psychology 2: 67-91.

Williams K. (2004) Can Urban Intensification Contribute to Sustainable Cities? An International Perspective City Matters.

Wolsink M. (2004) Policy beliefs in spatial decisions: contrasting core beliefs concerning space-making for waste infrastructure. Urban Studies 41: 2669-2690.

Woodcock I, Dovey K, Wollan S, et al. (2011) Speculation and Resistance: Constraints on Compact City Policy Implementation in Melbourne. Urban Policy and Research 29: 343-362. 
Figure 1: Illustrated statements used in this study

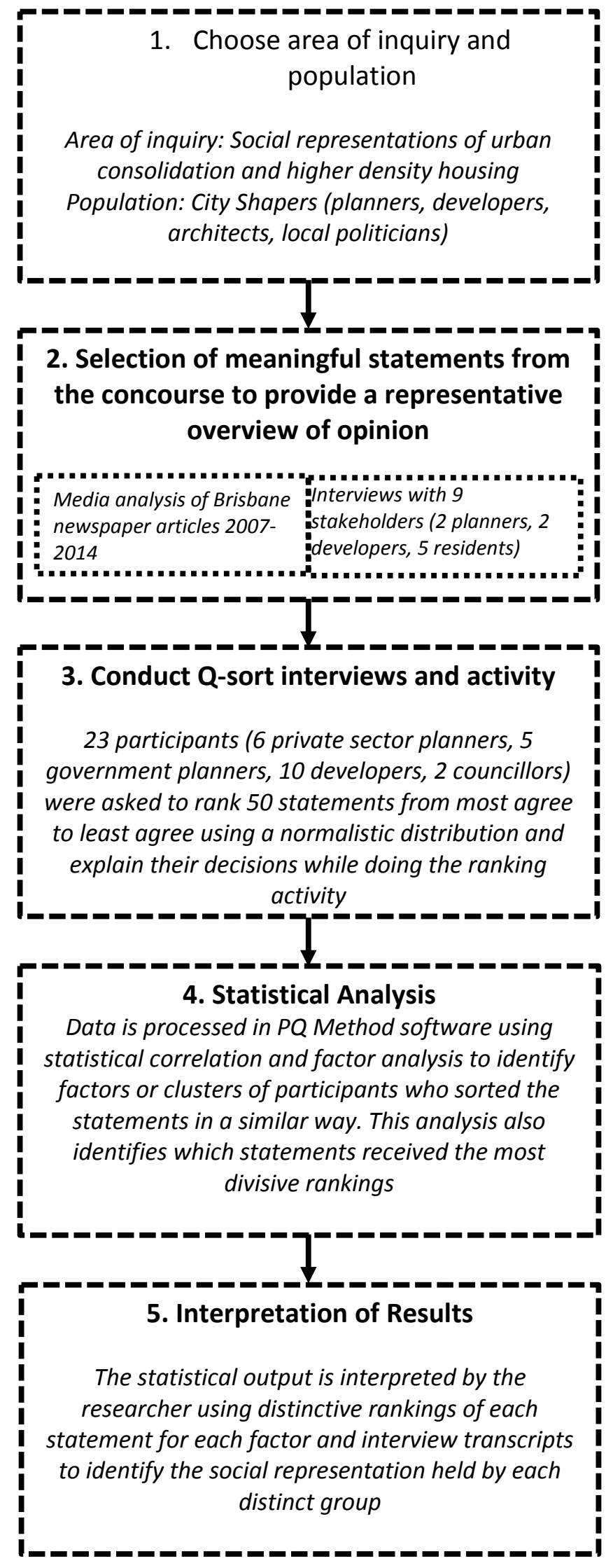

2. The concourse is "the flow of communicability surrounding any topic" in "the ordinary conversation, commentary and discourse of every day life." (Brown 1993).

3. Participants placed statements on an answer board in the pattern shown in figure $x$. This allowed them to rank statements based on level of agreement

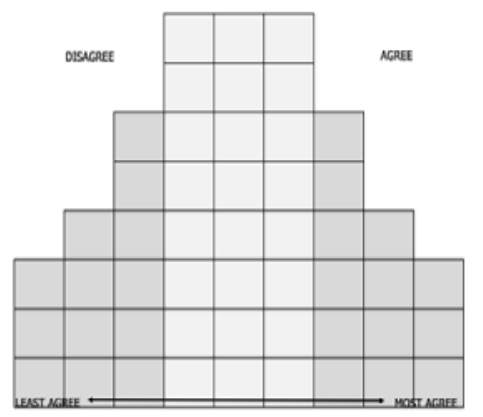

4. A four step inverted factor analysis was employed. 1) An inter-correlation matrix was calculated. 2) Factors are axtracted mathematically. This study used 3 factors as this solution provided the 'best fit.' 3) A varimax rotation was applied to make results more easily interpretable. 4) Factor scores were computed and related back to the statements to allow for interpretation of results 
Table 1: All Q-sort statements

\begin{tabular}{|c|c|c|c|c|}
\hline & Statement & F1 & $\mathbf{F 2}$ & F3 \\
\hline 1 & $\begin{array}{l}\text { What drives me insane is that we have all these plans and strategies and most of the time they are } \\
\text { completely ignored. What's the point of a neighbourhood plan if it doesn't get enforced? }\end{array}$ & 4 & -3 & 0 \\
\hline 2 & $\begin{array}{l}\text { The issue with planning in Brisbane is that development is considered in election cycles, there isn't } \\
\text { enough foresight to deliver successful higher density }\end{array}$ & 2 & 3 & 2 \\
\hline 3 & $\begin{array}{l}\text { If we increase high density living then we can lower our carbon footprints and we can invest in better } \\
\text { public transport - it's better for the environment }\end{array}$ & -4 & 1 & 4 \\
\hline 4 & $\begin{array}{l}\text { The problem with living in apartments is that you can't have any individuality, everything has to conform. } \\
\text { Body corporate rules can get ridiculous }\end{array}$ & 0 & -2 & -3 \\
\hline 5 & $\begin{array}{l}\text { Residents are having high density foisted upon them without consultation or the ability to have a say in } \\
\text { how their neighbourhoods develop }\end{array}$ & 3 & -4 & 0 \\
\hline 6 & Apartments are only suitable for investors and the young, trendy inner-city cafe crowd & 2 & -3 & -4 \\
\hline 7 & $\begin{array}{l}\text { I like that everyone in my neighbourhood is relatively like-minded. We all have similar values and } \\
\text { lifestyles }\end{array}$ & 1 & -1 & -2 \\
\hline 8 & $\begin{array}{l}\text { I think people get used to the noises of living in units, it's like living next to a train track, you stop noticing } \\
\text { it }\end{array}$ & -1 & 0 & 1 \\
\hline 9 & $\begin{array}{l}\text { People living in densifying areas should be rubbing their hands together, not complaining. All they have to } \\
\text { do is sell their property to the right person and they'll clean up }\end{array}$ & 0 & 2 & -2 \\
\hline 10 & $\begin{array}{l}\text { It's stupid to underdevelop an inner-city site as permissable building heights are always going to increase } \\
\text { and you'll miss potential profit }\end{array}$ & -1 & 0 & -2 \\
\hline 11 & $\begin{array}{l}\text { Densification has a place in housing provision but it isn't enough to meet all our needs. It has to be } \\
\text { supplemented by greenfield development. That's where all the demand is }\end{array}$ & 3 & 3 & -1 \\
\hline 12 & $\begin{array}{l}\text { I understand that planning policy is aiming for high levels of infill housing but I don't think that is what is } \\
\text { actually occurring on the ground- it's a great ideology but it isn't reality }\end{array}$ & 1 & -1 & -1 \\
\hline 13 & $\begin{array}{l}\text { As much as Gen } \mathrm{Y} \text { is all about convenience, I think once they start to pair up and have kids they'll still want } \\
\text { to move to the suburbs with some grass under their feet }\end{array}$ & 3 & 0 & 1 \\
\hline 14 & $\begin{array}{l}\text { Brisbane should be making much more use of things like infill and subdivision of people's large back } \\
\text { gardens to create opportunities for new dwellings }\end{array}$ & 2 & 3 & -1 \\
\hline 15 & $\begin{array}{l}\text { There is a pretty antagonistic relationship between planners and developers these days - planners often } \\
\text { see their role as delaying and reducing development }\end{array}$ & 3 & 0 & -4 \\
\hline 16 & I think Brisbane has failed to supply sufficient infrastructure to support increased population and densities & -1 & 2 & 1 \\
\hline 17 & $\begin{array}{l}\text { Developers need the flexibility to develop something economically feasible even if it doesn't completely } \\
\text { conform with the plan. }\end{array}$ & 1 & 4 & 3 \\
\hline 18 & $\begin{array}{l}\text { We need NIMBYs that are passionate and care because you need someone fighting for balance. Leave it } \\
\text { to capitalism and we might oversteer }\end{array}$ & -2 & -2 & 1 \\
\hline 19 & $\begin{array}{l}\text { There is huge demand for housing, we can't build it fast enough and yet developers still seem to have to } \\
\text { bash their head against a wall to bring the community on board or get councils to move }\end{array}$ & 2 & 2 & -3 \\
\hline 20 & $\begin{array}{l}\text { I think there is a cultural change taking place in our attitudes towards apartments. In the } 90 \text { s we thought } \\
\text { they were pigeon holes that belonged in Hong Kong }\end{array}$ & -2 & 2 & 4 \\
\hline 21 & I'm happy to live in a single room with a kitchenette so long as it's in my price range and close to the city. & -3 & 1 & -2 \\
\hline 22 & I don't really need to buy a house. If I never saw anything I liked, or could afford, I'd be happy to rent & -2 & 1 & 0 \\
\hline 23 & $\begin{array}{l}\text { SEQ is already over-crowded, we could solve all our traffic and housing affordability issues by just slowing } \\
\text { population growth }\end{array}$ & -3 & -4 & -3 \\
\hline 24 & $\begin{array}{l}\text { There's no need to go building more and more and more suburbs further and further out, it's just } \\
\text { ridiculous really. They are taking up good farming land and natural habitats }\end{array}$ & -4 & -3 & 0 \\
\hline 25 & The best thing about apartments is the convenience - easy access and easy maintenance & 0 & 3 & 2 \\
\hline 26 & $\begin{array}{l}\text { It's tragic to see Brisbane losing its tin and timber character as developers carve up our suburbs and build } \\
\text { out-of-place apartment buildings }\end{array}$ & 0 & -3 & -1 \\
\hline
\end{tabular}




\begin{tabular}{|c|c|c|c|c|}
\hline 27 & $\begin{array}{l}\text { The real issue of allowing one high density development to occur in a suburb is that it sets a precedent } \\
\text { and leaves the floodgates open for future development }\end{array}$ & 1 & -4 & 1 \\
\hline 28 & $\begin{array}{l}\text { We concentrate too much on local communities in development decisions, what about people who want } \\
\text { to move there in the future? Or the people who use the neighbourhood but don't live there? }\end{array}$ & 0 & 1 & -1 \\
\hline 29 & $\begin{array}{l}\text { The increasing take-up of medium density development close to the inner city and built up areas would } \\
\text { suggest that there is a market for it, otherwise developers would stop building it }\end{array}$ & -1 & 4 & 4 \\
\hline 30 & $\begin{array}{l}\text { We let developers get away with designing cheap and dodgy buildings so they keep building them like } \\
\text { that }\end{array}$ & 1 & -2 & 2 \\
\hline 31 & $\begin{array}{l}\text { While most people would prefer their neighbourhoods to remain low-density, I think most people realise } \\
\text { that isn't possible given our growing population }\end{array}$ & 0 & 2 & -2 \\
\hline 32 & $\begin{array}{l}\text { Increasing housing supply through infill development will increase affordability. We desperately need } \\
\text { more housing to stop the housing and rental crisis }\end{array}$ & -2 & 4 & 0 \\
\hline 33 & $\begin{array}{l}\text { We only want large backyards because that was what we grew up with, unlike in European cities where } \\
\text { they're used to higher density living. People just don't like change }\end{array}$ & -3 & -1 & 3 \\
\hline 34 & $\begin{array}{l}\text { Apartment blocks will become the ghettos of the future as residents who don't care about their upkeep } \\
\text { move in }\end{array}$ & 2 & -2 & -3 \\
\hline 35 & $\begin{array}{l}\text { I think people get very upset about developments in their area but once they are built they kind of forget } \\
\text { about it and things go back to normal }\end{array}$ & -1 & 1 & 2 \\
\hline 36 & $\begin{array}{l}\text { If you're going to have high rise you must have green space or else we're going to have a lot of very } \\
\text { psychotic people }\end{array}$ & 1 & 1 & 3 \\
\hline 37 & $\begin{array}{l}\text { Part of the issue is greed - developers are just out to maximise yields so they slap on the highest building } \\
\text { they can get approved and don't consider anything else }\end{array}$ & 0 & -2 & 1 \\
\hline 38 & $\begin{array}{l}\text { Affluent suburbs are lucky because they have far more power to protect themselves from high-rise } \\
\text { development }\end{array}$ & 0 & -2 & 1 \\
\hline 39 & I don't think people have a problem with density. I think they have a problem with bad design of density. & -1 & -1 & 2 \\
\hline 40 & $\begin{array}{l}\text { There are very severe constraints on the amount of land available for greenfield development and that's } \\
\text { what makes housing unaffordable }\end{array}$ & 4 & 2 & -1 \\
\hline 41 & $\begin{array}{l}\text { It's only fair for people to fight to maintain their quality of life and property values, even if it comes at the } \\
\text { expense of others }\end{array}$ & 2 & -1 & 0 \\
\hline 42 & $\begin{array}{l}\text { It's common to have a much better sense of community in a vertical community (aka apartment) than in } \\
\text { the suburbs }\end{array}$ & -2 & -1 & -4 \\
\hline 43 & $\begin{array}{l}\text { A lot of people get lured into chasing the dream of the big house and garden and end up enslaved to a } \\
\text { bank. Better to live somewhere smaller and save your money for the things you love }\end{array}$ & -1 & 0 & 1 \\
\hline 44 & As our population grows the poor people are going to get pushed further and further from the city centre. & 1 & 0 & 3 \\
\hline 45 & $\begin{array}{l}\text { Bringing up kids in higher density is actually easier because you have better access to high quality parks } \\
\text { and other facilities. }\end{array}$ & -4 & 0 & -2 \\
\hline 46 & $\begin{array}{l}\text { Brisbane's CBD isn't high enough. The higher we go, the more walkable our cities will become and it'll be } \\
\text { easier to get around because public transport will be better }\end{array}$ & -3 & 1 & 0 \\
\hline 47 & $\begin{array}{l}\text { I think Brisbane is really well planned. The areas of higher density are supported by facilities and easy } \\
\text { access to transport so they can easily support more people }\end{array}$ & -2 & 1 & 0 \\
\hline 48 & $\begin{array}{l}\text { For me, apartments are a stepping stone. They suit certain points in your life but mostly they just help you } \\
\text { work your way up to a detached house. }\end{array}$ & 1 & -1 & -1 \\
\hline 49 & $\begin{array}{l}\text { The community consultation process is really a game. Community groups, politicians and developers are } \\
\text { just playing off each other to negotiate the best results for themselves }\end{array}$ & 4 & -1 & 2 \\
\hline 50 & $\begin{array}{l}\text { Brisbane is way ahead of Sydney and Melbourne as it actually has the opportunity to have a plan because } \\
\text { it isn't big enough yet to be constrained. }\end{array}$ & -1 & 0 & -1 \\
\hline
\end{tabular}

